\title{
Assessing the driving forces for greening business practices: Empirical evidence from the United Arab Emirates' logistics service industry
}

\author{
L. Salhieh and I. Abushaikha* \\ School of Management and Logistics Sciences, German-Jordanian University, P. O. Box: 35247, Amman 11180, Jordan \\ *To whom all correspondence should be addressed \\ ismail.abushaikha@gju.edu.jo
}

\begin{abstract}
The uprising economic, social and political pressures on achieving a good level of environmental governance have forced companies to adopt business practices that aim to mitigate $\mathrm{CO} 2$ emissions. Logistics industry is considered as one of the major areas that could make a considerable improvement in reducing the environmental impact of business activities. The aim of this study is to investigate the driving forces that influence the adoption of environmentally friendly logistics activities. Following a detailed literature review, a theoretical model, which encompassed several driving forces and logistics activities, has been developed. Survey-based quantitative data were collected from logistics service providers in the United Arab Emirates (UAE) and analysed using structural equation modelling methodology and multiple regression analysis. Through answering 110 questionnaires, respondents holding different managerial levels at logistics service organizations, provided data reflecting their perception of the forces that would influence the adoption of green logistics practices. The driving forces (legislations, customers, and organizational awareness) were found to influence the adoption of green logistics practices by the logistics service industry in the areas of warehousing, packaging and transportation.
\end{abstract}

\section{Introduction}

Since the early 1970s, as economic pressures on businesses began to grow, companies started to look for new practices to improve the efficiency of their operations through a better management of material and resources flows (Grawe, 2009). Therefore, logistics; that is planning the flow of material and information in an efficient and effective way with the supply chain partners (Grawe, 2009; McKinnon, 2015) was given considerable attention. Since then, many companies have recognized logistics management as tool that could make substantial operational improvements and support their competitiveness in the marketplace. However, the growing economic, social and political pressures on achieving a good level of environmental governance have forced companies to prioritize their efforts to mitigate the environmental impact of their operations (Tacken, Rodrigues \& Mason, 2013; Ackers, 2015). In particular, logistics operations are considered as a major source of the $\mathrm{CO} 2$ emissions that are responsible for global warming (Tacken et al., 2013). In recent years, the term green logistics has become a buzzword, which refers to efforts to measure and mitigate the ecological impact of logistics activities, and became a challenge to today's supply chain managers (Lau, 2011). Painting logistics "green" is a complex matter, because there are basic inconsistencies between "greenness" and "logistics". Four basic paradoxes contribute to these inconsistencies, which include costs, time/speed, reliabilities and warehousing (Rodrigue, Slack \& Comtois, 2001). However, there are driving forces for "greenness" that are forcing firms to adopt green practices throughout their operations, which include mounting energy costs, worldwide alarms among corporate over Greenhouse Gases (GHG) emissions, climate change, governmental regulations and increased community awareness of environmental issues. This study tackles green logistics practices from this narrow sense focusing mainly on three activities, namely, transportation, warehousing, and packaging. Hence, this study tries to understand the driving forces for the adoption of green logistics practices with a particular reference to the logistics service providers in the United Arab Emirates (UAE). The UAE was chosen as the context of this research due to the importance of the logistics industry to its economy. According to the logistics performance index (LPI) report developed by the World Bank, UAE was ranked top amongst Arab Countries and $27^{\text {th }}$ worldwide (Arvis, Saslavsky, Ojala, Shepherd, Busch \& Raj, 2014), which reflects the economic growth and logistics competitiveness of the country. UAE has successfully capitalized on its potential as an excellent logistics hub, with billions of dollars being invested in the fast-track development of warehousing facilities and transportation infrastructure (Haq, 2011). UAE's logistics market is expected to reach USD 9.4 billion during 2014. With this fast growth in the logistics market, the demand for logistics services has been growing significantly in UAE. The aim of this study is to investigate the perception of logistics managers of the driving forces and consequently green logistics practices adopted in transportation, warehousing and packaging activities in their companies. Therefore, the main research question of this study is developed.

$R Q$ : What are the drivers for adopting green logistics practices by logistics service providers (LSPs)?

Hence, this study contributes to extant literature in several ways. First, this study is important when viewed in relation to 
today's concerns and pressures for organizations to meet environmental regulations and social responsibility (Ackers, 2015; Holt \& Ghobadian, 2009; Zhu, Sarkis, \& Geng, 2005; Zhu, Sarkis \& Lai, 2007; Zhuang \& Synodinos, 1997). The need to mitigate the impact of business logistics activities on the environment is constantly increasing. Companies are redesigning their logistics practices to make the activities more energy efficient and environmentally friendly. Green supply chain initiatives in manufacturing, distribution and recycling are rapidly emerging as major trends (Mason, 2002). Consequently, green logistics has become an important consideration and a big challenge to supply chain management around the globe (Murphy \& Poist, 2000; Rao \& Holt, 2005; Vachon \& Klassen, 2006). As a result, the examination of the driving forces that influence the adoption of green logistics practices is important to the development of green climates within organizations.

The remainder of this paper is structured as follows. The next section proposes the research framework, and research hypothesis. The third section presents a description of the research methodology used, and the fourth section presents the data analysis including discussion of the findings. The final section introduces the conclusions, limitations, contributions and future research suggestions.

\section{Literature review}

Recent years have witnessed a great increase in research related to different aspects of sustainability (Rauer \& Kaufmann, 2015; Ackers, 2015; Bjorklund \& Forslund, 2013; Carter \& Rogers, 2008; McKinnon, 2003; Wu \& Dunn, 1995; Nikbakhsh, 2009; Sarkis, 2003). Sustainability is an emerging business megatrend that is causing a fundamental shift in the competitiveness landscape (Lubin \& Esty, 2010; Ackers, 2015) and rapidly becoming a key driver of innovation (Nidumolu, Prahalad \& Rangaswami, 2009). As such, supply chains nowadays are considering the adoption of a variety of sustainability initiatives in order to achieve a competitive advantage (Lau, 2011), or at least maintain a competitive parity. Literature in the area of sustainable logistics is still underdeveloped and the implications regarding adoption and diffusion of green practices are not well understood (Diabat \& Govindan, 2011). From a broader perspective, green logistics is regarded as part of green supply chain management (GSCM) that aims at integrating environmental thinking into closed-loop supply chain management (Lau, 2011).

\section{Driving forces and pressures for green logistics}

Investigation of pressures and drivers for adopting and improving environmental performance arises from a number of external and internal groups or stakeholders (Ackers, 2015). Various pressures affect the implementation of green logistics including external and internal factors. External factors mostly linked to stakeholder pressure, while internal factors are mostly related to specific business-led strategic processes (Testa \& Iraldo, 2010). The literature suggests that different types of drivers have different relative levels of priority and that legislation is the most cited influential external driver (Rao, 2002; Preuss, 2002; Ackers, 2015). Governments through regulation can both encourage and discourage the adoption of green practice (Ackers, 2015). Governments can provide financial incentives, pilot projects, and tax breaks to stimulate green practices for logistics service providers. However, a more important matter is the perception of managers and governments in enforcing these laws and the costs of breaching them (Holt, 1998; Rao, 2002). The literature has identified a number of potential groups that will influence organizational adoption of green logistics and other environmental practices. Institutional theory has been used to understand how companies adopt, assimilate, and develop initiatives such as total quality management (Anderson, Daly \& Johnson, 1999), lean manufacturing (Ketokivi \& Schroeder, 2004), Six Sigma (Braunscheidel et al., 2011), and supply chain management practices (Zhu et al., 2005; Zhu, Geng, Fujita \& Hashimoto, 2010; Lee \& Cheong, 2011; Zailani, Eltayeb, Hsu \& Tan, 2012) successfully. The growth in adoption of green practices has been affected by institutional pressures driven by market and regulatory demands (Bansal, 2005; Kumar \& Putnam, 2009). Most developed and developing countries have by now created regulations that require firms to make green policies for their supply chains. Thus, firms are required to implement green business strategies because of the increased external pressure for sustainability (Lewis \& Gertsakis, 2001; Ackers, 2015 ) in the form of compulsory environmental regulations related to green supply chain management (Kilbourne, 2006). Carter, Ellram, and Ready (1998) stressed that pressures from internal stakeholders within the organization could constitute green awareness. López- Gamero, Molina-Azorín, and Claver-Cortés (2010) found that when the environmental strategies are driven from green awareness rather than legislation, their effect on environmental management is significantly higher. Hart and Ahuja (1996) demonstrated that firms that have early awareness may be opting for more advanced environmental strategies that build on low emissions.

However, while regulatory pressures may serve as a driver for environmental action, it is not the only determinant, which affects the establishment of environmental management processes (Bansal \& Roth, 2000; Davidson \& Worrell, 2001; Rothenberg, 2007). Other forces can originate from stakeholders such as competitors, employees and customers (Bansal \& Roth, 2000; Callens \& Wolters, 1998; Darnall, 2006; Davidson \& Worrell, 2001; Pan, 2003). Customers within the supply chain (Christmann \& Taylor, 2001; Chan \& Lau, 2001) can be a major driver for improving the environmental performance of enterprises and could constitute a pressure of green barriers to commodities. Bansal (2005) found that the institution's international experience, media pressure and organizational size may also affect the development of environmental management practices. Forces other than customers or other stakeholders may also affect corporate sustainable development and motivate a firm to obtain an environmental certificate. Pan (2003) found that one stimulus may be a perceived marketing advantage (i.e. image), when many competitors were already ISO 14000 certified, or awareness of the benefits experienced by other 
certified companies and the avoidance of a potential export barrier.

Based on the literature review, there are many driving forces investigated by researchers in order to explain what factors affect firms' adoption of green practices. These included stakeholder pressure, environmental regulations, company size, and managers' characteristics. Firms in different industries may react differently to environmental concerns (Etzion, 2007; Ackers, 2015), and the logistics industry may react to environmental problems differently from the manufacturing industries (Lin \& Ho, 2009). This study has identified three driving forces to investigate the perception of managers regarding these forces: customers, legislations, and organizational awareness. These are considered as the most popular pressures in extant management literature on sustainability (Bansal \& Roth, 2000; Davidson \& Worrell, 2001; Rothenberg, 2007; Callens \& Wolters, 1998; Darnall, 2006; Pan, 2000) as discussed earlier in this paper. The customers' driver is identified as the perception of the pressure that being exerted by the users of the products or the local community (Etzion, 2007). The legislations' driver measures managers' perception of the pressure by governments to enforce environmental legislations (Lee, 2008), and the economic benefits/costs of abiding/breaching these regulations (Rao \& Holt, 2005; Crumrine, Russell \& Geyer, 2004). The last driver measures the organization attempts to diffuse green logistics awareness programs among managers.

\section{Green logistics practices}

For more than two decades now academic research has been giving increased attention to the logistics service industry (Wu \& Dunn, 1995; Maloni \& Carter, 2006; Lieb \& Lieb, 2010). Wu and Dunn (1995) argue that the logistics service industry could have a more value-added role by providing "green" logistics, which in turn allows their customers to produce even "greener" products and services for endcustomers. Green logistics considered as part of environmental management systems within organizations, and several studies conducted to understand the external or internal implementation forces behind environmental management systems initiatives (Darnall 2006; Davidson \& Worrell, 2001; Melnyk, Srouf \& Calantone, 2003; Pan, 2003).

In transportation, a green strategy would consist of maximizing the capacity of delivery trucks by the consolidation of orders (Rao, Grenoble \& Young, 1991). Another green solution in transportation may exist in central planning of transport operations, which requires the use of routing and scheduling software such as GPS and in-cab communication (Rushton et al., 2006; Wu \& Dunn, 1995). When using road transport, a green transport practice would be to increase fuel efficiency through the training of drivers. A company can also reduce fuel consumption and pollution by a good maintenance of their fleet. Consequently, it is advisable to follow preventive maintenance programs because slipping clutches, blocked air filters, fuel leaks, poorly inflated tires and binding brakes are sources of inefficient consumption of fuel resulting in higher $\mathrm{CO} 2$ emission. For companies that are not specialized in freight transport a good option would be to collaborate with a third party logistics provider (3PL) who may help with implementing green initiatives (Rushton et al., 2006). In an environmentally friendly transportation system, essential elements of a transportation system such as type of transport, fuel sources, infrastructure, operational practices and organization, are considered. These elements and the dynamics that connect them, determine the environmental impact generated in the transportation logistics phase of the supply chain (Kam, Smyrnios \& Walker, 2003). Wu and Dunn (1995: 32) argued that transportation is the "single largest source of environmental hazard in the logistics system". In order to achieve a more environmentally friendly logistics system, they argue, one should thus make logistics decisions that minimize the amount of transport emissions through changes in the mode of transport, transport demand, or vehicle utilization. Although improvements in any of the aspects would lead to improved environmental performance, the effect on logistics efficiency and effectiveness is not necessarily guaranteed. Previous studies suggested that the general perception among shippers is that a shift to less polluting transport modes would lead to a general decrease in logistics performance (Ludvigsen, 1999; Evers, Harper \& Needham, 1996). Reduced transport demand is also a key to improved environmental performance. This can be generally met by reduced transport frequency or the tendency to local sourcing rather than offshore sourcing (Wu \& Dunn, 1995; Cooper, Browne \& Peters, 1991).

Packaging design is also considered as an activity that would be managed in a way that reduces the environmental impact of logistics activities. In green logistics, the challenge is to design packaging systems to get goods from production to consumption without damage using the minimum amount of resources and generating the least amount of waste. When packaging reduced then fewer resources are used. The emphasis of green packaging practices has been on the use of recycled packaging materials, and environmentally friendly packaging design to reduce waste (Crumrine et al., 2004). The use of packaging whether, it is made of glass, metal, paper or plastic, contributes heavily to the solid waste stream. In order to address these environmental impacts of packaging, many countries have programs and legislations that aim to minimize the amount of packaging that enters the waste stream, such as the Packaging Directive in the EU (EUROPEN, 2015).

In the field of warehousing, we can find several practices that can be part of sustainable developments such as implementing energy efficient building practices (e.g. installing energy efficient motors and lighting, solar panels and switch fuel). The main objective is to save energy and water where possible. Increasing the sustainability awareness amongst the warehouse's operators and supervisors would be also of a great benefit (Lieb \& Lieb, 2010; Rushton et al., 2006). Green running of warehouses can start with the training of the staff at an environmental level. Training of the staff is very important to teach them how to work and to 
behave in an energy efficient way and encouraging them to maintain the warehouse equipment such as forklifts and their batteries regularly (Rushton et al., 2006). Monitoring gas and electricity consumption, developing pilot programs in order to reduce energy consumptions at a warehouse (Lieb \& Lieb, 2010). Other practices that can be used to improve recue environmental impact of warehouse activities is through shifting to a more centralized distribution systems (Beamon, 1999; Mckinnon, 2015), or “consolidating a company's warehousing network" (Lieb \& Lieb, 2010: 531) where inventory would be gathered at one larger place which may lead to lower use of resources.

Given that there is a multidimensional expansion of the literature in the area of corporate environmental management, this paper focuses on three green logistics practices namely transportation, warehousing, and packaging. These considered as the most widely performed logistics activities by logistics service providers (Lieb \& Lieb, 2010; Rushton, Croucher \& Baker, 2006; Maloni \& Carter, 2006). The green logistics practice is evaluated as a multidimensional construct consisting of one dimension that takes account of several green practices. To measure the green logistics practices, we considered green practices in three logistics areas: transportation as related to roadway mode, packaging, and warehousing. The study did not consider other areas such as purchasing, port management or different modes of transportation as they are beyond the control of the investigated study population.

Rodrigue et al. (2001) argued that the paradoxes of "greenness" and "logistics" of (costs, time/speed, reliabilities and warehousing) could influence managers' perception of the magnitude of these forces and consequently their adoption of such green practices. Figure 1 shows a force-field analysis of the adoption of green logistics practices. Force-field analysis is an influential technique in social sciences developed by Kurt Lewin (Lan \& Lee, 2007). It is used to look at the factors that would influence a situation characterized by conflict. The force-field analysis identifies the key factors that justify the change to a new situation and the factors restrict such a change. The impact of each factor (force) can be estimated through representing the driving forces and their restraining forces using diagrams. Force field analysis approach has been successfully implemented in operations management research (Lan \& Lee, 1997; Salaheldin, 2003). The diagram shown below argues that a manager perception of the magnitude of the driving forces against the paradoxes would or would not initiate a process of adopting green logistics practices within the organization. Therefore, this study is trying to measure the magnitude of the driving forces, from managers' perception, in forcing organizations to adopt green logistics practices in the UAE's logistics service industry.

\section{Adoption of Green Logistics Practices}

Against (Paradoxes)

Pro (Driving Forces)

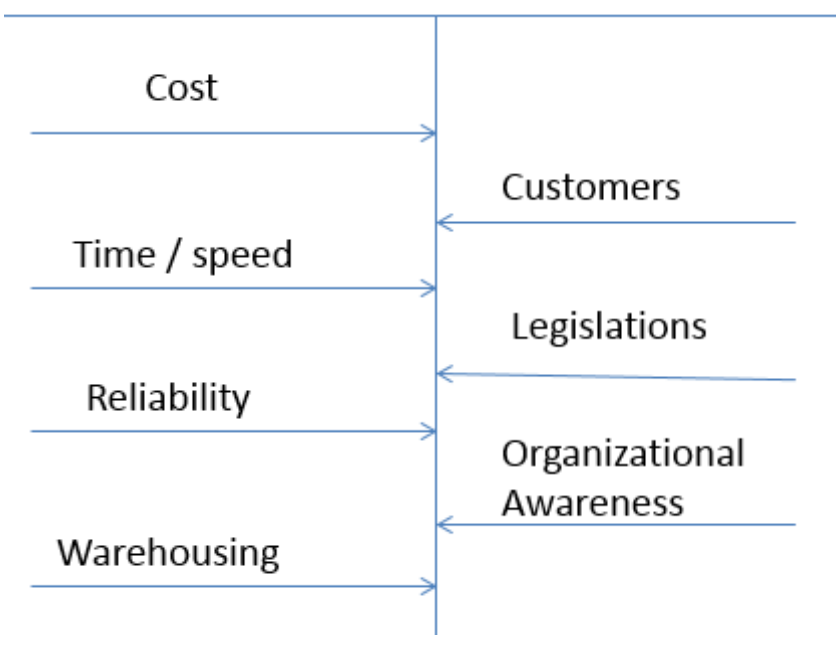

\section{Figure 1: Force field analysis of adopting green logistics practices}

Based on the above discussion and the force field analysis shown in Figure 1, this study argues that in order for organizations to adopt green business practices in the logistics service industry, the total strength of all driving forces must be greater than the total strength of all restraining forces (paradoxes). Therefore, the study proposes the following hypothesis:

\begin{abstract}
Ha: The total relative strength of the driving forces has a positive influence on green logistics practices adoption for UAE logistics companies from the managers' perception.
\end{abstract}

In order to test the hypothesis, it is important to define each of the intervening concepts: the strength of introducing the driving forces and green logistics practices. The strength of introducing the driving forces is evaluated as a multidimensional construct consisting of one dimension that takes account of legislations, customers and organizational awareness. Measurement of the driving force concept is based on a latent model, which assumes that the dimensions of the multidimensional construct are statements of the latent construct. In other words, the latent variable is understood to be the cause of its dimensions. The study measured each dimension with a set of items that reflect the respondent's opinion concerning the different drivers of green logistics. Each of the investigated green logistics practices is seen as being a latent factor that is measured through its corresponding items.

The aim of this study is to assess the influence of certain driving forces on the adoption of green logistics practices. In order to achieve this aim, a research framework has been developed as illustrated in Figure 2. The framework is a simple linear model of the relationship between independent variable and dependent variable. Driving force as the 
independent variable consists of three constructs namely customers, legislations, and organizational awareness forces. The model therefore examines the driving forces as organizational resources in determining the adoption of green logistics practices.

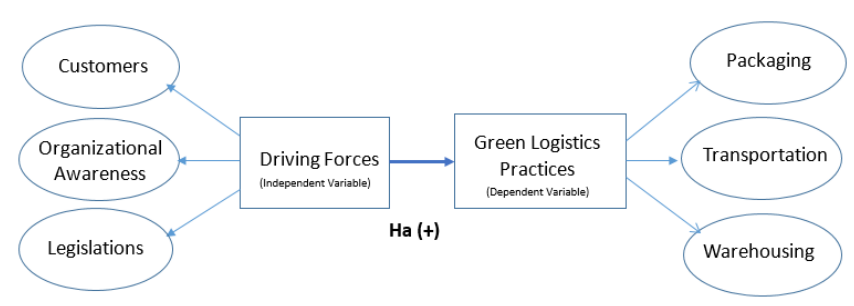

Figure 2: Research framework

Having developed the research model, the next section discusses the research methods and analyses the results.

\section{Methods}

\section{Instrument development}

The two major dimensions outlined in the research framework include green logistics practices, and the driving force. The first dimension addresses the green logistics practices measures, which include three activities: transportation, warehousing and packaging. These three constructs were measured using five-point Likert scale anchored by "strongly disagree" and "strongly agree". Table 1 shows the measurement items for each construct. These constructs were deduced based on extant literature and authors' practical experiences. The extant literature of green logistics and sustainability (e.g. Lieb \& Lieb, 2010; Maloni \& Carter, 2006; Lau, 2011; Wu \& Dunn, 1995) provided an important source for understanding the green logistics practices in several contexts which helped developing the questionnaire and its items. The authors' previous practical experiences in the logistics function at several organizations especially in the logistics service industry also provided a rich source for developing the questionnaire items.

The second dimension is the driving force dimension, which includes three constructs: customers, legislations and organizational awareness. These constructs were measured using five-point Likert scales anchored by "strongly disagree" and "strongly agree". Table 2 shows the measurement items for each construct. These constructs and their items were developed based on a detailed review of extant literature on sustainability in the area of logistics and supply chain management (e.g. Rao, 2002; Preuss, 2002; Hart \& Ahuja; 1996) and strategic management (e.g. Bansal, 2005; Bansal \& Roth, 2000; Kumar \& Putnam, 2009; Callens \& Wolters, 1998). The items were then developed as to obtain data in the context of the UAE logistics service industry.

\section{Table 1: Green logistics practices (LOGP)}

\section{Green logistics practices: Transportation (TT)}

The company's trucks used are usually loaded to full capacity.

The company's trucks used are maintained regularly, with special emphasis on fuel-efficiency.

The company's truck drivers are trained in fuel-efficient driving, e.g. in how to minimize idling, when to shut down the engine etc.

The company's truck drivers' performance in fuel-efficiency is constantly monitored.

The company uses effective routing and scheduling to minimize travel distance and time.

The third-party company's truck delivery service used is known for fuel-efficiency.

Green logistics practices: Packaging (TP)

The company's packaging design perfectly fits onto international standard pallet sizes and allows for effective space utilization.

The company's packaging material can be easily reused.

The company's packaging material is easy to recyclable.

The company's packaging material is biodegradable.

Green logistics practices: Warehousing (TW)

The company is aware of techniques in energy efficiency in the warehouse construction.

The company is aware of techniques in energy efficiency for the warehouse management and operation, such as efficient lighting systems in its warehouse facilities, roofs consisting of heat- and sunlight reflecting material, or solar panels.

The acquisition of equipment for energy efficiency is an important factor.

The company's warehouse staff is trained on energy-efficiency.

The movement of the warehouse vehicles is managed to minimize the travel distance through proper sequencing of storage and retrieval tasks.

The company's warehouse equipment is maintained regularly. 
Table 2. Green logistics drivers (driver)

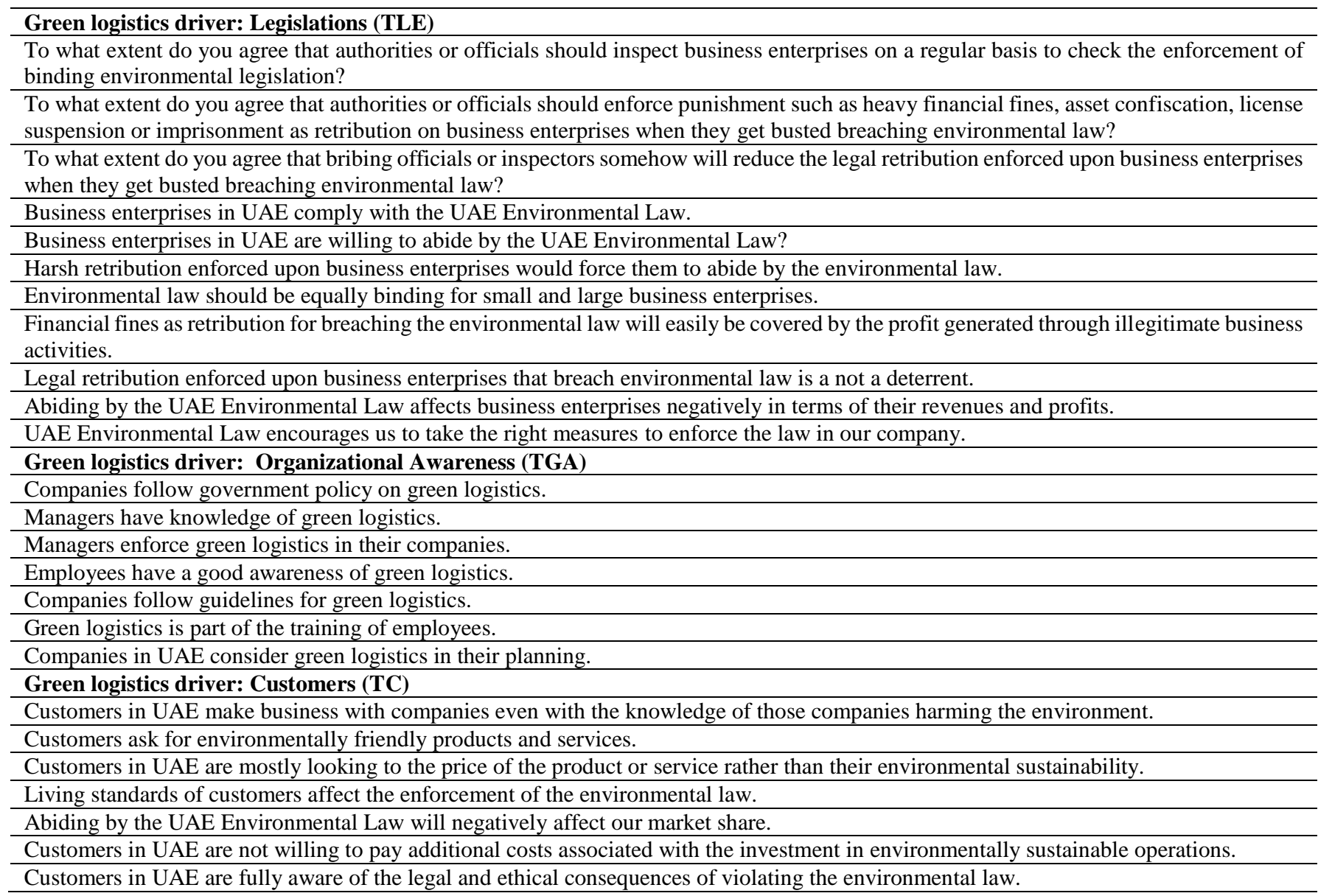

\section{Data collection}

The target population for this study was the firms operating in the UAE whose primary functions are warehousing, packaging and transportation. We selected these types of organizations, as they collectively comprise a broad and, to a large extent, generalizable perspective of organizations commonly found within supply chains. The sampling frame of the study was derived from individuals in these organizations who showed willingness to participate in responding to the questionnaire. The data collection process consisted of two stages. The first stage involved contacting 33 potential companies through phone calls and field visits in order to ask them about the possibility of participation in this research. A secondary researcher (a graduate student of management) performed this process. Most of the companies contacted showed willingness to participate and were given a copy of the research questionnaire. This stage allowed the researchers to be introduced to other potential companies who were suggested by the contacted companies. Furthermore, conducting the first stage of data collection allowed the researchers to obtain an idea about the participating companies in this study. The second stage involved emailing the questionnaires to the companies who were suggested during the first stage. As a result, hundred twenty organizations were contacted to solicit participation. Invitations for participation were e-mailed to a high-ranking person in each of the hundred twenty firms. The respondent was the logistics manager/ operations manager/ chief operations officer or equivalent senior logistics officer/ executive at each company. A hundred-ten individuals completed the initial questionnaire. After a thorough review of the surveys submitted, a hundred were deemed to be complete and therefore useable. This is considered a high response rate, which was obtained because of the structured data collection process through conducting a two-stage method.

Because each respondent held the position of manager or executive, he or she is assumed to be well versed in the organizational aspects of their firm, which increased the reliability of data collected (Philips, 1981). The use of a single respondent is appropriate in this situation because this individual was in a position of decision-making authority over logistics activities (Liu, Ke, Wei, Gu \& Chen, 2010). The use of survey responses from a single key respondent in this context provides a well-rounded picture of the firm-level of green logistics adoption practices in a supply chain environment. Tabachnick and Fidell (2007) discuss the ratio of cases to independent variables and the issues associated with smaller sample sizes. This is a limitation within the study but the total number of respondents was similar to a range of previous studies that used statistical analysis including those of Klassen and Whybark (1999), Rao (2002), and Zsidisin 
and Hendrick (1998). Therefore, whilst the sample is relatively small, it remains a valid size for this exploratory study.

\section{Data analysis}

Data analysis for this study involved two major phases: the data reduction process and the structured relationship analysis (SEM). The aim of the data reduction process is to reduce the number of variables and parameters to manageable number in terms of the ratio between sample size and parameters estimated in the SEM. The structured relationship analysis used to assess the simultaneous relationship between the driving forces and green logistics practices as well as assessing the relationships among the logistics practices.

\section{Data reduction process}

The purpose of data reduction process is to collapse the six constructs identified in this paper into composite variables. Three constructs (customers, legislations, organizational awareness) constitute driving forces latent variables, and three constructs (packaging, transportation, warehousing) constitute green logistics practices.

In order to obtain valid and reliable estimates of the constructs of interest, this study followed the steps involved in the development and validation of the measurement scale as suggested by Sureshchandar, Rajendran and Anantharaman (2002). Validity and reliability tests administered on the research framework constructs before a single score calculated to represent each construct. Confirmatory Factor Analysis (CFA) using SPSS assessed how well each item measured the scale. The CFA approach was used as we used a model developed from the literature (Rao, 2002; Preuss, 2002; Hart \& Ahuja; 1996; Lieb \& Lieb, 2010; Maloni \& Carter, 2006; Lau, 2011; Wu \& Dunn, 1995) and the authors had good knowledge of the factors need to explain the relationships amongst the measured variables.

The unidimesionality of the measure is needed in order to ensure the construct validity and reliability. In order to check for unidimensionality, a measurement model is specified for each construct and CFA is run for all the different constructs of the research framework. Individual items in the model were examined to ensure to what degree they represent the same construct (Sureshchandar et al., 2002). A comparative fit index (CFI) of 0.90 or above for the model means that there is a strong evidence of unidimensionality. The CFI indices for all the constructs presented in the developed model are shown in Table 3.

Reliability refers to the ability to yield consistent results (Nunnally, 1978). The reliability analysis was conducted by calculating the Cronbach's alpha for each scale, which exceeded the threshold point of 0.7 (Nunnally, 1978) as reported in Table 3. A construct validity was conducted in order to test the degree to which a test measures what it claims to be measuring. As a result, none of the items was deleted. The Goodness of Fit Indices (GFI) of the constructs exceeded the 0.9 criterion, thus, establishing the construct validity as reported in Table 3. Based on the findings of previous tests, the composite measure of each construct measured by calculating their means values (Hair, Anderson, Tatham \& Black, 1998) shown in Table 3. The individual measurement scales appeared to be unidimensional, reliable and valid and the fit of the measurement model is considered sufficient to support further assessment of the structural model.

Table 3. Construct validity, reliability, and the values for composite measures

\begin{tabular}{l|c|c|c|c|c|c}
\hline \multicolumn{1}{c|}{ Construct } & $\begin{array}{c}\text { No, of items } \\
\text { (Final) }\end{array}$ & $\begin{array}{c}\text { Comparative } \\
\text { fit index (CFI) }\end{array}$ & $\begin{array}{c}\text { Goodness of } \\
\text { fit index }\end{array}$ & $\begin{array}{c}\text { Means } \\
\begin{array}{c}\text { Standard } \\
\text { deviation }\end{array}\end{array}$ & $\begin{array}{c}\text { Cronbach's } \\
\text { alpha }\end{array}$ \\
\hline Green logistics practices: Transport & 6 & 0.931 & 0.972 & 3.888 & 0.014 & 0.857 \\
\hline Green logistics practices: Packaging & 4 & 0.974 & 0.993 & 3.684 & 0.001 & 0.798 \\
\hline Green logistics practices: Warehousing & 6 & 0.921 & 0.982 & 3.845 & 0.011 & 0.883 \\
\hline Green logistics driver: Legislation enforcement & 11 & 0.911 & 0.931 & 3.783 & 0.012 & 0.867 \\
\hline $\begin{array}{l}\text { Green logistics driver: organizational } \\
\text { awareness }\end{array}$ & 7 & 0.958 & 0.962 & 3.903 & 0.016 & 0.890 \\
\hline Green logistics driver: Customers & 7 & 0.923 & 0.951 & 3.837 & 0.017 & 0.791 \\
\hline
\end{tabular}

As evident from Table 4, all correlations are positive and relatively strong. This indicates that driving forces do complement each other and there is a strong relationship among these forces. The three green logistics practices appear to have strong correlations amongst themselves except between packaging and warehousing. Firms that excel in one area of green logistics practices are also likely to excel in other areas of green logistics practices. The correlations between the driving forces and the green logistics practices are also relatively stronger indicating that these constructs are distinct to each other. 
Table 4: Correlations among constructs

\begin{tabular}{|c|c|c|c|c|c|c|c|}
\hline & & TLE & TC & TGA & TT & TW & TP \\
\hline \multirow[t]{3}{*}{ TLE } & Pearson Correlation & 1 & $.928^{* * *}$ & $.915^{* *}$ & $.815^{* *}$ & $.395^{*}$ & $.943^{* *}$ \\
\hline & Sig. (2-tailed) & & .000 & .000 & .000 & .032 & .000 \\
\hline & $\mathrm{N}$ & 100 & 100 & 100 & 100 & 100 & 100 \\
\hline \multirow[t]{3}{*}{$\mathrm{TC}$} & Pearson Correlation & & 1 & $.945^{* * *}$ & $.851^{* *}$ & $.387^{*}$ & $.899^{* * *}$ \\
\hline & Sig. (2-tailed) & & & .000 & .000 & .038 & .000 \\
\hline & $\mathrm{N}$ & & 100 & 100 & 100 & 100 & 100 \\
\hline \multirow[t]{3}{*}{ TGA } & Pearson Correlation & & & 1 & $.858^{* *}$ & $.333^{*}$ & $.924^{* *}$ \\
\hline & Sig. (2-tailed) & & & & .000 & .020 & .000 \\
\hline & $\mathrm{N}$ & & & 100 & 100 & 100 & 100 \\
\hline \multirow[t]{3}{*}{ TT } & Pearson Correlation & & & & 1 & $.388^{*}$ & $.864^{* *}$ \\
\hline & Sig. (2-tailed) & & & & & .036 & .000 \\
\hline & $\mathrm{N}$ & & & & 100 & 100 & 100 \\
\hline \multirow[t]{3}{*}{ TW } & Pearson Correlation & & & & & 1 & .238 \\
\hline & Sig. (2-tailed) & & & & & & .066 \\
\hline & $\mathrm{N}$ & & & & & 100 & 100 \\
\hline \multirow[t]{3}{*}{ TP } & Pearson Correlation & & & & & & 1 \\
\hline & Sig. (2-tailed) & & & & & & \\
\hline & $\mathrm{N}$ & & & & & & 100 \\
\hline
\end{tabular}

Note:

Correlation is significant at the 0.01 level (2-tailed).**

Correlation is significant at the 0.05 level (2-tailed).*

\section{Structured equation modelling}

For model generation purposes (Joreskog, 1993) structural equation modelling (SEM) is used. When an initial model does not fit the data, it needs to be adjusted by deleting, adding, and/or modifying paths in the model, and then retested using the same data set. The aim of this process is to establish a theoretical sense model and reasonable correspondence to the data. The conceptual structured equation model in Figure 2 was tested using SPSS Amos. In the structural model, the parameters estimated (Standardized $\mathrm{R}$ square reported by SPSS Amos) using the maximum likelihood method and the best competing model shown in Figure 3.

Based on the strong correlation reported in Table 4. The conceptual proposed model improved by adding covariance between error terms. (e.g. TLE and TC). Therefore, adding the covariance results in the original hypothesized framework as shown in Figure 3, which also contains the standardized estimates. The model fit indices (NFI $=0.991, \mathrm{CFI}=1, \mathrm{IFI}=$ 1.001, GFI $=0.994$, AGFI $=0.961$, RMSEA $=.000)$, $\mathrm{CMIN} / \mathrm{DF}=0.261$, and $\mathrm{p}$-value $=0.898)$ show that the model fits the data well with a sample size $(n=100)$. The path from driver construct to green logistics practices $(b=0.954$, $p$-value $=0.026)$ were found to be significant at 0.05 level. This supports our research hypothesis, postulating that drivers of greenness lead to the adoption of green logistics practices within organizations. Based on the evidence of unidimensionality of the latent variables, multiple regression analysis was conducted in order to find out which driving forces have more influence on organization to adopt green logistics practices shown in Figure 4. It is evident that all three driving forces are significant at 0.05 levels.

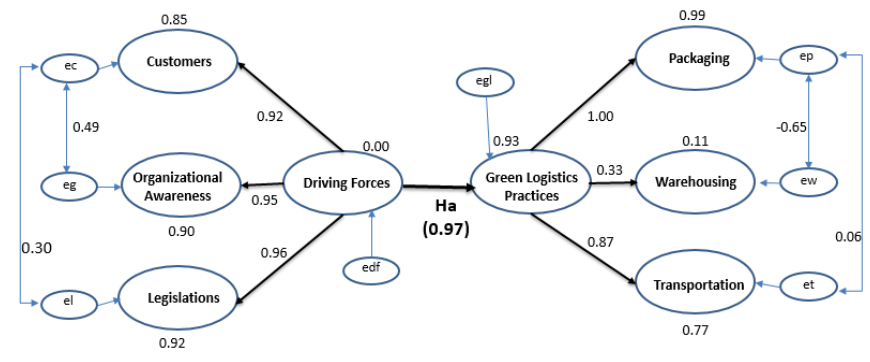

Figure 3: Path estimates for the structured model

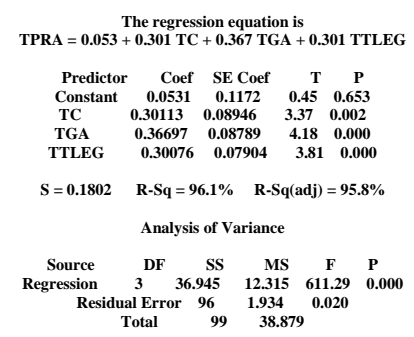

Figure 4: Multiple regression analysis

\section{Conclusions and future research}

In recent years, environmental issues have become a major concern all over the world. Companies in UAE are under increasing pressure to adopt green practices in order to mitigate the environmental impact of their logistics activities. This study focused on understanding the pressures faced by the logistics service providers (LSPs) for greening their operations. Due to the lack of research on environmental responsibility in UAE logistics industry, this research contributes to the extant literature through providing an insight into the adoption of green logistics practices in UAE logistics service industry. This study proposes a model that provides some explanations as to the drivers that influence the adoption of green logistics practices. The study has used 
a questionnaire survey, that was developed based on extant literature in the field of sustainability and green logistics and the authors own practical experiences in the logistics service industry, to collect data on green logistics practices specifically in the areas of warehousing, packaging and transportation. Data were also collected concerning the driving forces that might influence the adoption of green logistics practices including customers, legislations and organizational awareness.

The research findings reveal a high moderate level of green logistics practices among UAE logistics companies. Moreover, the findings suggest that driving forces have significant positive influences on green logistics practices adoption for UAE logistics companies (Ha). The study has demonstrated a strong correlation between separate driving forces and separate green logistics practices as evident by Table 4. All constructs that represent the driving forces have a significant effect on the adoption level of green logistics practices as evident from the regression analysis. Our study suggests that customer pressure on adoption of green logistics practices is significant, contrary to other studies (e.g. Holt \& Ghobadian, 2009) who found that this factor has a low level of impact on the adoption of green logistics practices. This study also suggests that its finding of customer significance can be contributed to other driving forces in place such as the enforcement of legislations and green awareness programs within the organization. Other driving forces might work as pressure on the company to pay more attention to respond to customer pressure.

Our study has only considered specific areas of logistics activities and specific driving forces that have been identified and used in the literature of green logistics. The influence of other possible drivers on UAE logistics companies' green logistics practices adoption behaviour can be taken into consideration in future studies. In addition, because this study focuses on green logistics practices of UAE logistics companies, the research findings may be limited in their generalizability. Different countries, industrial sectors, and green logistics practices may lead to different conclusions according to the context of the study (Liu, Ke, Wei \& Hua, 2013; Gimenez, van der Vaart \& van Donk, 2012). Hence, future studies may use the proposed model in other countries or contexts to enhance the generalizability of the findings. Furthermore, many companies still believe that there is a trade-off between adopting green logistics practices and firm's economic benefits. However, this level of argument was excluded from the empirical investigation in this study. Therefore, as a suggestion for future research, the analysis of this paradox between the drivers of adopting green logistics practices and the driving forces of economic benefits of green logistics practices are recommended for future research.

\section{References}

Ackers, B. 2015. 'Ethical considerations of corporate social responsibility - a South African perspective', South African Journal of Business Management, 46(1):11-21
Anderson, S.W., Daly, J.D. \& Johnson, M.F. 1999. 'Why firms seek ISO 9000 certification: regulatory compliance or competitive advantage?', Production and Operations Management, 8(1):28-43.

Arvis, J.F., Saslavsky, D., Ojala, L., Shepherd, P., Busch, C. \& Raj, A. 2014. Connecting to compete 2014 - Trade logistics in the global economy. Washington, DC: The International Bank for Reconstruction and Development/The World Bank.

Bansal, P. 2005. 'Evolving sustainably: A longitudinal study of corporate sustainable development', Strategic Management Journal, 26(3):197-218.

Bansal, P. \& Roth, K. 2000. 'Why companies go green: A model of ecological responsiveness', Academy of Management Journal, 43(4):717-36.

Beamon, B.M. 1999. 'Designing the green supply chain', Logistics Information Management, 12(4): 332 - 342

Bjorklund, M. \& Forslund, H. 2013. 'The purpose and focus of environmental performance measurement systems in logistics', International Journal of Productivity and Performance Management, 62(3):230-249.

Braunscheidel, M.J., Hamister, J.W., Suresh, N.C. \& Star, H. 2011. 'An institutional theory perspective on Six Sigma adoption', International Journal of Operations \& Production Management, 31(4):423-451.

Callens, I. \& Wolters, L. 1998. 'Factors of unsustainability; identification, links and hierarchy', Business Strategy and the Environment, 7(1): 32-42.

Carter, C.R. \& Rogers, D.S. 2008. 'A framework of sustainable supply chain management: Moving toward new theory', International Journal of Physical Distribution \& Logistics Management, 38(5):360-87.

Carter, C.R., Ellram, L.M. \& Ready, K.J. 1998. 'Environmental purchasing: Benchmarking our German counterparts', International Journal of Purchasing \& Materials Management, 34(4):28-38.

Chan, R.Y.K. \& Lau, L.B.Y. 2001. 'Explaining green purchasing behavior: A cross-cultural study on American and Chinese consumers', Journal of International Consumer Marketing, 14(2/3):9-41.

Christmann, P. \& Taylor, G. 2001. 'Globalization and the environment: determinants of firm self-regulation in China', Journal of International Business Studies, 32(3):439-58.

Cooper, J., Browne, M. \& Peters, M. 1991. European logistics: Markets, management and strategy, Blackwell, Oxford.

Crumrine, B., Russell, P. \& Geyer, R. 2004. Green packaging: A guideline and tools for environmentally sound packaging practices for computer and electronics products. [online]. URL www.bren.ucsb.edu/services/student/GP/green_packaging.pdf

Darnall, N. 2006. 'Why firms mandate ISO 14001 certification', Business and Society, 45(3):354-81.

Davidson, W.N. III \& Worrell, D.L. 2001. 'Regulatory pressure and environmental management infrastructure and practices', Business and Society, 40(3)315-42. 
Diabat, A. \& Govindan, K. 2011. 'An analysis of the drivers affecting the implementation of green supply chain management', Resources, Conservation and Recycling, 55(6):659-667

Etzion, D. 2007. 'Research on organizations and the natural environment, 1992-present: A review', Journal of Management, 33(4):637-664.

EUROPEN 2015. EU packaging and packaging waste directive. [online]. http://www.europen-packaging.eu/policy/5-eu-packagingand-packaging-waste-directive.html/ Accessed: 3 June 2015.

Evers, P.T., Harper, D.V. \& Needham, P.M. 1996. 'The determinants of shipper perceptions of modes', Transportation Journal, 36(2):13-25.

Gimenez, C., van der Vaart, T. \& van Donk 2012. 'Supply chain integration and performance: The moderating effect of supply complexity', International Journal of Operations \& Production Management, 32(5):583-610

Grawe, S.J. 2009. 'Logistics innovation: A literature-based conceptual framework', International Journal of Logistics Management, 20(3):360-77.

Hair, J., Anderson, R., Tatham, R. \& Black, W. 1998. Multivariate Data Analysis. 5th ed. London: Prentice-Hall.

Haq, R. 2011. Country profile: UAE logistics report 2011. [online]. URL: http://www.arabiansupplychain.com/article-5623-countryprofile-uae-logistics-report-2011/

Hart, S.L. \& Ahuja, G. 1996. 'Does it pay to be green? An empirical examination of the relationship between emission reduction and firm performance', Business Strategy and the Environment, 5(1):30-37.

Holt, D. \& Ghobadian, A. 2009. 'An Empirical Study of Green Supply Chain Management Practices amongst UK Manufacturers', Journal of Manufacturing Technology, 20(7):933-956.

Holt, D. 1998. 'The perceived benefits of an environmental management standard', Business Process Management, 4(3): 204213.

Joreskog K., 1993. Testing structural equation models. In: Bollen KA, Long JS, Bollen KA, Long JS, (Ed.). Testing structural equation models. Newbury Park: Sage.

Kam, B., Smyrnios, G.C. \& Walker, R.H. 2003. Strategic business operations, freight transport and eco-efficiency: A conceptual model. Sheffield: Greenleaf.

Ketokivi, M.A. \& Schroeder, R.G. 2004. 'Strategic, structural contingency and institutional explanations in the adoption of innovative manufacturing practices', Journal of Operations Management, 22(1):63-89.

Kilbourne, W.E. 2006. 'The role of the dominant social paradigm in the quality of life/environmental interface', Applied Research in Quality of Life, 1(1):39-61.

Klassen, R.D. \& Whybark, D.C. 1999. 'The impact of environmental technologies on manufacturing performance', Academy of Management Journal, 42(6):599-615.
Kumar, S. \& Putnam, V. 2009. 'Cradle to cradle: Reverse logistics strategies and opportunities across three industry sectors', International Journal of Production Economics, 115(2): 305-315.

Lan, L.L. \& Lee, J. 1997. 'Force-field analysis on policies affecting working women in Singapore', Journal of Management Development, 16(1): 43-52

Lau, K.H. 2011. 'Benchmarking green logistics performance with a composite index', Benchmarking: An International Journal, 18(6):873-896.

Lee, K.-H. \& Cheong, I.-M. 2011. 'Measuring a carbon footprint and environmental practice: The case of Hyundai Motors Co. (HMC)', Industrial Management \& Data Systems, 111(6):961-978.

Lee, S. 2008. 'Drivers for the participation of small and mediumsized suppliers in green supply chain initiatives', Supply Chain Management: An International Journal, 13(3):185-98.

Lewis, H. \& Gertsakis, J. 2001. Design + environment: A global guide to designing greener goods. Sheffield: Greenleaf Publishing.

Lieb, K.J. \& Lieb, R.C. 2010. 'Environmental sustainability in the third-party logistics (3PL) industry', International Journal of Physical Distribution \& Logistics Management, 40(7):524-33.

Lin, C.Y. \& Ho, Y.H. 2009. 'RFID technology adoption and supply chain performance: an empirical study in China's logistics industry', Supply Chain Management: An International Journal, 14(5):369378.

Liu, H., Ke, W., Wei, K.K. \& Hua, Z. 2013. 'Effects of supply chain integration and market orientation on firm performance: Evidence from China', International Journal of Operations \& Production Management, 33(3):322-346.

Liu, H., Ke, W., Wei, K.K., Gu, J. \& Chen, H. 2010. 'The role of institutional pressures and organizational culture in the firm's intention to adopt internet-enabled supply chain management systems', Journal of Operations Management, 28(5):372-84.

López-Gamero MD, Molina-Azorín JF. \& Claver-Cortés E. 2010. 'The potential of environmental regulation to change managerial perception, environmental management, competitiveness, and financial performance', Journal of Cleaner Production, 18(10/11): 963-974.

Lubin, D.A. \& Esty, D.C. 2010. 'The sustainability imperative: Lessons for leaders from previous game-changing megatrends', Harvard Business Review, 88(5):42-50.

Ludvigsen, J. 1999. 'Freight transport supply and demand conditions in the Nordic Countries: Recent evidence', Transportation Journal, 39(2):31-54.

Maloni, M.J. \& Carter, C.R. 2006. 'Opportunities for research in third-party logistics', Transportation Journal, 45(2): 23-38.

Mason, S. 2002. 'Backward progress: Turning the negative perception of reverse logistics into happy returns'. IIE Solutions, 34(8):42-6.

McKinnon, A.C. 2003. Logistics and the environment, In D Hensher and K Button (Ed.) Handbook of Logistics and Supply Chain Management. Amsterdam: Elsevier. 
McKinnon, A.C. 2015. Environmental sustainability: A new priority for logistics managers, In McKinnon, A.C., Browne, M., Piecyk, M. and Whiteing, A. (Ed.) Green logistics: improving the environmental sustainability of logistics. KoganPage Publishers.

Melnyk, S.A., Srouf, R.P. \& Calantone, R. 2003. 'Assessing the impact of environmental management systems on corporate and environmental performance', Journal of Operations Management, 21(3):329-51.

Murphy, P.R. \& Poist, R.F. 2000. 'Green logistics strategies: An analysis of usage patterns', Transportation Journal, 40(2):5-16.

Nidumolu, R., Prahalad, C.K. \& Rangaswami, M.R. 2009. 'Why sustainability is now the key driver of innovation', Harvard Business Review, 87(9):56-64.

Nikbakhsh, E. 2009. Green supply chain management. In Farahani, R.Z., Davarzani, H. and Asgari, N. (Ed.), Supply Chain and Logistics in National, International and Governmental Environment, Heidelberg : Physica-Verlag HD

Nunnally, J. 1978. Psychometric theory, 2nd ed., New York: McGraw-Hill.

Pan, J-N. 2003. 'A comparative study on motivation for and experience with ISO 9000 and ISO 14000 certification among far Eastern countries', Industrial Management \& Data Systems, 103(8):564-78.

Philips, J. 1981. 'Assessing measurement error in key informant reports: A methodological note on organizational analysis in marketing', Journal of Marketing Research, 18(4):395-415.

Preuss, L.L. 2002. 'Green light for greener supply', Business Ethics: A European Review, 11(4): 308-317.

Rao, K., Grenoble, W. \& Young, R. 1991. 'Traffic congestion and JIT', Journal of Business Logistics, 12(1):105-22.

Rao, P. 2002. 'Greening the supply chain: A new initiative in South East Asia'. International Journal of Operations \& Production Management, 22(6):632-55.

Rao, P. \& Holt, D. 2005. 'Do green supply chains lead to competitiveness and economic performance?', International Journal of Operations \& Production Management, 25(9):898-916.

Rauer, J. \& Kaufmann, L. 2015, 'Mitigating external barriers to implementing green supply chain management: A grounded theory investigation of green-tech companies' rare earth metals supply chains', Journal of Supply Chain Management, 51(2):65-88

Rodrigue, J-P., Slack, B. \& Comtois, C. 2001. Green logistics (the paradoxes of). In A. M. Brewer, K. J. Button and D. A. Hensher (Ed.), The handbook of logistics and supply-chain management. Second Edition London: Pergamon/Elsevier.

Rothenberg, S. 2007. 'Environmental managers as institutional entrepreneurs: Rhe influence of institutional and technical pressures on waste management', Journal of Business Research, 60(7):74957.

Rushton, A., Croucher, P. \& Baker, P. 2006. The handbook of logistics and distribution management. Third Edition, London and Philadelphia: Kogan Page.
Salaheldin, S.I. 2003 'The implementation of TQM strategy in Egypt: A field-force analysis', The TQM Magazine, 15(4): 266-274

Sarkis, J. 2003. 'A strategic decision framework for green supply chain management', Journal of Cleaner Production, 11(4):397-409.

Srivastara, S.K. 2007. 'Green supply-chain management: A state-ofthe-art literature review', International Journal of Management Reviews, 9(1):53-80.

Tabachnick, B.G. \& Fidell, L.S. 2007. Using multivariate statistics, 5th ed., Boston: Allyn \& Bacon.

Sureshchandar, G.S., Rajendran, C. \& Anantharaman, R.N. 2002. 'Determinants of customer-perceived quality: A confirmatory factor analysis approach', Journal of Services Marketing, 16(1): 9-34

Tacken, J., Rodrigues, V.S. \& Mason, R. 2013. 'Examining CO2 reduction within the German logistics sector', The International Journal of Logistics Management, 25(1):54-84

Testa, F. \& Iraldo, F. 2010. 'Shadows and lights of GSCM (green supply chain management): determinants and effects of these practices based on a multi-national study', Journal of Cleaner Production, 18(10/11):953-962.

Vachon, S., \& Klassen, R. D. 2006. 'Extending green practices across the supply chain: The impact of upstream and downstream integration', International Journal of Operations and Production Management, 26(7):795-821.

Wu, H.J. \& Dunn, S. 1995. 'Environmentally responsible logistics systems', International Journal of Physical Distribution \& Logistics Management, 25(2):20-38.

Zailani, S.H.M., Eltayeb, T.K., Hsu, C.C. \& Tan, K.C. 2012. 'The impact of external institutional drivers and internal strategy on environmental performance', International Journal of Operations \& Production Management, 32(6):721-745.

Zhu Q, Sarkis J. \& Geng Y. 2005. 'Green supply chain management in China: Pressures, practices and performance', International Journal of Operations \& Production Management, 25(5):449-468.

Zhu, Q., Geng, Y., Fujita, T. \& Hashimoto, S. 2010. 'Green supply chain management in leading manufacturers: Case studies in Japanese large companies', Management Research Review, 33(4):380-392.

Zhu, Q., Sarkis, J. \& Lai, K. 2007. 'Green supply chain management: Pressures, practices and performance within the Chinese automobile industry', Journal of Cleaner Production, 15(11/12):1041-52.

Zhuang, L. \& Synodinos D. 1997. 'Legislation for the environment: does it work? An empirical study into selected UK-based chemical manufacturing firms', Management Decision, 35(7):508-18.

Zsidisin, G.A. \& Hendrick, T.E. 1998. 'Purchasing's involvement in environmental issues: A multi-country perspective', Industrial Management \& Data Systems, 98(7):313-20. 